\title{
Ellipsis
}

\section{(as if only we've come back again)}

Michelle Antoinette

University of New Orleans, New Orleans

Follow this and additional works at: https://scholarworks.uno.edu/ellipsis

\section{Recommended Citation}

Antoinette, Michelle (2021) "(as if only we've come back again)," Ellipsis: Vol. 46 , Article 4.

DOI: https://doi.org/10.46428/ejail.46.04

Available at: https://scholarworks.uno.edu/ellipsis/vol46/iss1/4

This Poetry is brought to you for free and open access by the Department of English and Foreign Languages at ScholarWorks@UNO. It has been accepted for inclusion in Ellipsis by an authorized editor of ScholarWorks@UNO. For more information, please contact scholarworks@uno.edu. 


\section{(as if only we've come back again) \\ by Michelle Antoinette}

... found bleeding into a swarm, a step away from a pit-empty

tuna cans and condom wraps or to build a fire

ask for this

Secret Crick

a lip-locked slither prying mountains' gritty fold, dragging mountain down to this twice -told shore, a dam, poise in the tented pitch

- listen slept on splintered ground

when we woke. This

was how the river

broke.

When the copperhead, when the meadow bows, slip

into this handsewn skirt of ivory and sunset and lapis lazuli

and we'll cross the tributary by foot 